INVITED REVIEW

\title{
Glucocorticoids and Cardiovascular Disease
}

\author{
Brian R Walker \\ Endocrinology Unit, Queen's Medical Research Institute, Centre for Cardiovascular Science, University of Edinburgh, 47 Little France Crescent, \\ Edinburgh EH16 4TJ, Scotland, UK \\ (Correspondence should be addressed to B R Walker; Email: b.walker@ed.ac.uk)
}

This article is based on the presentation for the European Journal of Endocrinology Prize Lecture 2004 at the European Society of Endocrinology Meeting at Budapest, Hungary

\begin{abstract}
Chronic excessive activation of glucocorticoid receptors induces obesity, insulin resistance, glucose intolerance, dyslipidaemia and hypertension. Subtle abnormalities of the hypothalamic-pituitaryadrenal axis and/or of tissue sensitivity to glucocorticoids are also associated with these cardiovascular risk factors in patients with the metabolic syndrome. Furthermore, glucocorticoids have direct effects on the heart and blood vessels, mediated by both glucocorticoid and mineralocorticoid receptors and modified by local metabolism of glucocorticoids by the $11 \beta$-hydroxysteroid dehydrogenase enzymes. These effects influence vascular function, atherogenesis and vascular remodelling following intravascular injury or ischaemia. This article reviews the systemic and cardiovascular effects of glucocorticoids, and the evidence that glucocorticoids not only promote the incidence and progression of atherogenesis but also modify the recovery from occlusive vascular events and intravascular injury. The conclusion is that manipulation of glucocorticoid action within metabolic and cardiovascular tissues may provide novel therapeutic avenues to combat cardiovascular disease.
\end{abstract}

European Journal of Endocrinology 157 545-559

\section{Introduction}

Atherosclerosis and its occlusive vascular consequences remain the most common cause of death in many parts of the world. Several risk factors for the development of atheroma are amenable to treatment, including hypercholesterolaemia, hypertension, hyperglycaemia and cigarette smoking. Secular trends show that cardiovascular disease is declining in prevalence in the developed world, and that the outcome from events such as myocardial infarction is improving, in part due to modern cardiological interventions (1). However, there is concern that the pandemic of obesity and associated metabolic syndrome threatens to reverse these secular trends. In order to make further improvements in the prevalence and outcome of occlusive vascular disease and avoid the threat posed by obesity, we will need to understand more about the complex mechanisms that promote atheromatous plaque formation and instability and determine recovery following occlusive vascular events. This review is focused on the role of glucocorticoids in atherogenesis, and highlights emerging data which suggest that manipulation of glucocorticoid action has important potential in improving the outcome of occlusive vascular disease.

\section{Glucocorticoid signalling and the cardiometabolic responses to stress}

Glucocorticoids such as cortisol play a key role in the response to stress, including following sepsis, trauma, starvation and tissue ischaemia (2). Psychological stress can also activate the hypothalamic-pituitary-adrenal (HPA) axis, although in humans only selected psychological stimuli produce a robust increase in cortisol release. Cortisol induces a host of adaptive responses that may be homeostatic (adjusting systems to function normally in the face of a stressful environment) or allostatic (adjusting systems to function in a manner more appropriate to the stressful environment). Glucocorticoids provide a crucial 'brake' on innate inflammatory mechanisms, promoting resolution of inflammation (2). Many of these effects of glucocorticoids are relevant to cardiovascular and metabolic regulation, for example to maintain blood pressure in the face of septic shock or to promote efficient catabolism in the face of starvation.

Cortisol mediates its effects via activation of intracellular glucocorticoid receptors (GR: low affinity, type 2 corticosteroid receptors) and also mineralocorticoid receptors (MR: high affinity, type 1 corticosteroid receptors; Fig. 1A). GRs are ubiquitously expressed, but MRs are expressed only in selected tissues and at 

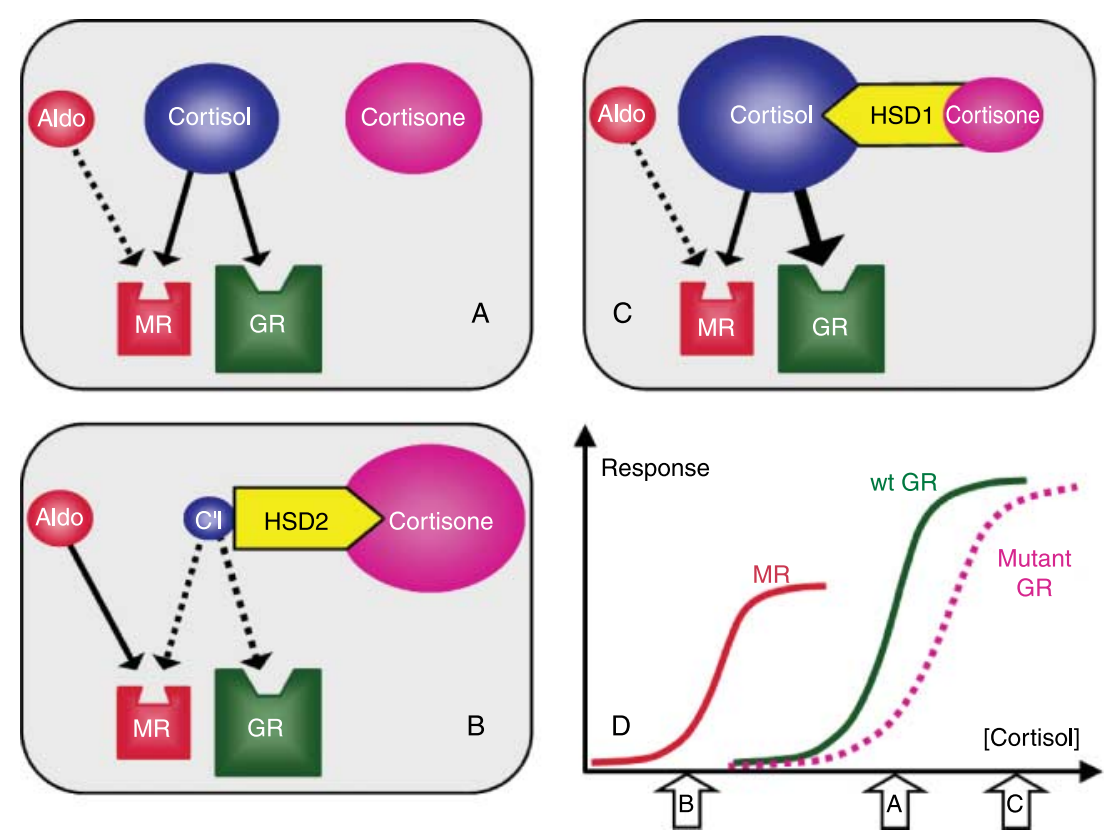

Figure $1 \mathrm{~A}$ model for the influence of $11 \beta$-HSDs and GR mutants on receptor occupancy. (A) In the absence of $11 \beta$-HSDs, intracellular cortisol and cortisone concentrations reflect free concentrations in plasma, which are substantially higher than those of aldosterone (Aldo). Cortisol occupies both high-affinity low-capacity MR and low-affinity high-capacity GR. Examples include hippocampal neurones and probably myocardium. (B) In the presence of $11 \beta-\mathrm{HSD} 2$, intracellular cortisol concentrations are reduced, excluding cortisol from both MR and GR and allowing access of aldosterone to MR. Examples are in the distal nephron, colon and sweat glands and in vascular endothelial cells. (C) In the presence of $11 \beta-H S D 1$, intracellular cortisol concentrations are increased. Occupancy of MR by cortisol may not increase, since capacity is limited, but occupancy of GR by cortisol is increased. Examples include vascular smooth muscle cells. $11 \beta$-HSD1 is also commonly expressed in cells which express GR but not MR, including hepatocytes, adipocytes, some areas of CNS and macrophages. (D) Tissue-specific differences in expression of $11 \beta$-HSDs may contribute to tissue-specific differences in glucocorticoid sensitivity in subjects

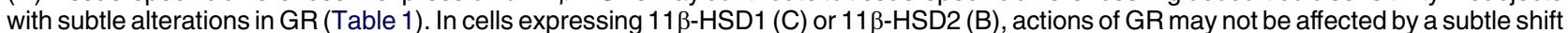
in the dose-response curve because intracellular cortisol concentrations are at the extreme ends of the dose-response curve where the response induced by mutant GR is not markedly different from wild type.

lower levels. In some sites (such as distal nephron, colon, salivary and sweat glands and vascular endothelium), MRs bind aldosterone exclusively because cortisol is excluded by local 'pre-receptor' inactivation by $11 \beta$-hydroxysteroid dehydrogenase type $2(11 \beta-$ HSD2, which converts cortisol to the inert 11-keto metabolite cortisone; Fig. 1B) (3). In other sites (classically in hippocampus and also probably in myocardium, vascular smooth muscle and adipose tissue), in the absence of $11 \beta$-HSD2, MRs are occupied by cortisol in competition with much lower prevailing concentrations of aldosterone (Fig. 1A and C). 11ßHSD1 is expressed in tissues that are important for metabolic (liver and adipose tissue), inflammatory (macrophage) and cardiovascular (vascular smooth muscle) function. 11ß-HSD1 is predominantly a reductase, regenerating active cortisol from inert cortisone and thereby amplifying GR activation (Fig. 1C) $(4,5)$.

These classical intracellular MRs and GRs act as transcription factors on $\sim 30 \%$ of genes, with the pattern of response in individual cell types dictated by the enormous complexity of interactions with heterodimers, co-activators and co-repressors, and epigenetic factors including chromatin organisation. To add to this complexity, there may be a role for non-genomic membrane receptor-mediated responses to glucocorticoids, but this remains of uncertain physiological relevance (6). Note that synthetic steroids vary in their susceptibility to metabolism by $11 \beta$-HSDs and in their binding affinities for GR and MR (7): $9 \alpha$-fluorocortisol ('fludrocortisone') resists metabolism by $11 \beta$ HSD2 but retains activity at both GR and MR, prednisolone is susceptible to metabolism by $11 \beta$ HSDs but is relatively selective for GR over MR, and dexamethasone is relatively resistant to $11 \beta$-HSDs (8) and a potent selective GR agonist.

The metabolic effects of glucocorticoids in the liver, adipose tissue, pancreas and brain have been reviewed elsewhere (9-11): broadly, glucocorticoids oppose the effects of insulin and increase turnover between stored energy (in glycogen, triglycerides and protein) and freely available fuel for mitochondrial oxidation (glucose and free fatty acids). Glucocorticoids also raise blood pressure, only in part mediated by renal sodium retention and plasma volume expansion $(12,13)$. In addition, both GR and MR are expressed in cardiovascular tissues including the heart and arterial walls, where glucocorticoids act directly to maintain vascular tone and modify vascular inflammatory, proliferative and remodelling responses to injury (see below, reviewed in (14-16)). 


\section{Glucocorticoids and risk factors for cardiovascular disease}

During chronic activation of the HPA axis, the effects of glucocorticoids may become maladaptive $(17,18)$. The metabolic and cardiovascular consequences are apparent in Cushing's syndrome, which is characterised by central obesity, insulin resistance, hyperglycaemia, dyslipidaemia and hypertension. Given the similarities between Cushing's syndrome and the metabolic syndrome, subtle abnormalities of cortisol secretion and action have been sought in subjects with this constellation of risk factors for cardiovascular disease (19).

\section{The HPA axis}

Activation of the HPA axis, with increased cortisol secretion rate and elevated morning plasma cortisol levels, has been associated with higher plasma glucose, triglycerides and blood pressure in several populationbased cohort studies (20). Relationships of plasma cortisol with obesity, however, are more complex, since obesity is associated with increased metabolic clearance rate of cortisol, which tends to lower plasma cortisol levels despite enhanced cortisol production rate (20). As a result, elevated plasma cortisol and obesity have independent and additive effects in predicting cardiovascular risk factors $(21,22)$.

Since it was popularised by Per Bjorntorp (23), the concept has spread that central obesity and metabolic syndrome are consequences of psychosocial stress, mediated by neuroendocrine stress responses including activation of the HPA axis. However, empirical evidence is inconsistent concerning the role of psychosocial stress - and, in particular, its role as the basis for HPA axis activation - in metabolic syndrome $(24,25)$. An alternative hypothesis is that activation of the HPA axis is a phenomenon 'programmed' by adverse events during early life which retard fetal growth. This is supported by associations between low birth weight and elevated plasma cortisol in adulthood, both in the basal state (26-28) and in response to stress (29-31). The molecular basis for this HPA axis activation remains uncertain, although it may involve epigenetic modification affecting transcription of GR $(32,33)$.

\section{Tissue sensitivity to cortisol}

In addition to control of cortisol action by the HPA axis, tissue sensitivity to cortisol may vary both between individuals and between tissues. Arguably, our understanding of the factors controlling tissue sensitivity to glucocorticoids (see above and Fig. 1) is simplistic, but we are at least beginning to understand the influence of variation in corticosteroid receptors and in pre-receptor steroid metabolism.

Simple bioassays, e.g. measuring the intensity of dermal vasoconstriction after overnight steroid application, suggest that tissue sensitivity to glucocorticoids is increased amongst subjects with cardiovascular risk factors (34-37). In part, this may be determined by variations in GR function (36). In metabolic syndrome, GR mRNA has been reported to be increased in skeletal muscle $(38,39)$ but not in adipose tissue $(40)$. As detailed in Fig. 2 and Table 1, polymorphisms in the GR gene, which influence in vitro receptor function, have been associated with cardiovascular risk factors including obesity (41). One might imagine that changes in GR function would not be cell-type specific, so that any change in sensitivity to cortisol in peripheral tissues would be compensated for by altered negative feedback control of the HPA axis and hence adjustment of circulating cortisol levels. Indeed, in very rare families with mutations in the GR gene causing autosomal dominant cortisol resistance, the resistance to cortisol does appear to be sufficiently uniform that the phenotype can be explained by increased ACTH secretion and hence excessive adrenal production of mineralocorticoids (11deoxycorticosterone) and androgens $(42,43)$. However, the GR polymorphisms shown in Fig. 2 and Table 1 probably influence interactions between GR and other transcription factors, and may not induce uniform changes in receptor signalling; indeed, the effects may be not only tissue specific but potentially gene specific. This is exemplified in the case of the Bcl1 polymorphism, which increases sensitivity of cortisol suppression by dexamethasone and of skin vasoconstriction by beclomethasone but paradoxically is associated with elevated plasma cortisol concentration (Table 2). Moreover, in vitro dose-response curves suggest that these polymorphisms are associated with subtle changes in sensitivity but not in maximum response to GR activation (44). The model in Fig. 1D illustrates that

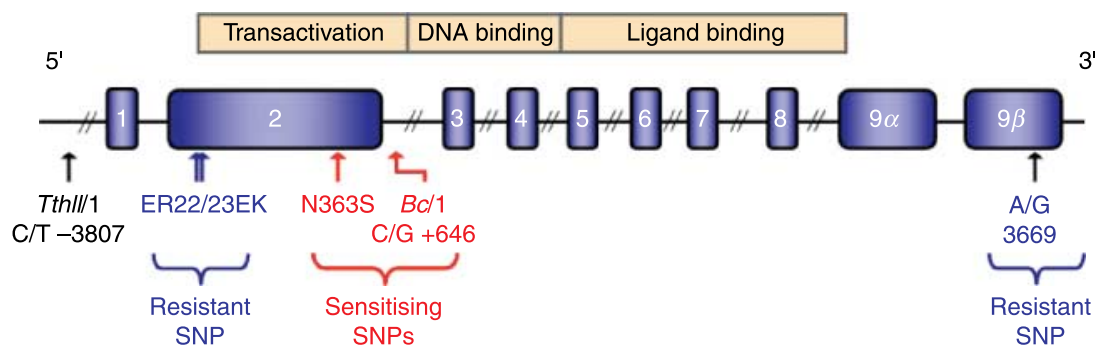

Figure 2 Common polymorphisms in the glucocorticoid receptor gene. Deleterious mutations causing autosomal dominant glucocorticoid resistance syndrome are clustered between exons 4 and 9 (not shown) and dramatically impact upon receptor binding to ligand or DNA. More common polymorphisms occur elsewhere as shown. Associated phenotypes are shown in Table 1. 
receptor occupancy and response depend upon intracellular cortisol concentrations, which, in turn, are influenced by intracellular glucocorticoid metabolism: thus, subtle variations in the GR dose-response curve may be more influential in some cells than in others, according to local expression of $11 \beta$-HSDs and whether the prevailing cortisol concentrations lie in a part of the dose-response curve which is markedly different between 'wild type' and 'mutant' GR. Since 11ß-HSD1 is expressed in cells involved in negative feedback regulation of the HPA axis (45), it is conceivable that these are relatively unaffected by GR polymorphisms.

Variations in $11 \beta$-HSD activity have also been linked with risk factors for cardiovascular disease. 11 $\beta$-HSD2 activity is deficient in a substantial minority of patients with essential hypertension $(46,47)$ and predicts salt sensitivity of blood pressure (48). $11 \beta$-HSD1 activity is increased in the adipose tissue of obese people (40, 4958 ) and predicts the severity of associated metabolic complications of obesity $(52,59,60)$. Inhibitors of $11 \beta$ HSD1 are in development for the treatment of type 2 diabetes and other features of metabolic syndrome, and have shown considerable promise in animal models (61-65) (see below).

The role of the HPA axis and variations in tissue sensitivity to cortisol in determining risk factors for cardiovascular disease in metabolic syndrome has been the subject of extensive research in the last decade and has been reviewed elsewhere $(19,20,41)$. Less attention has been paid to the role of cortisol in determining the incidence, progression and complications of atheromatous cardiovascular disease. Although one might infer from the associations of abnormalities of the HPA axis, GR and 11 $\beta$-HSD activity with cardiovascular risk factors that the same abnormalities would promote atherogenesis, this cannot be assumed since glucocorticoids also have effects within the blood vessel wall, which may modify effects mediated by systemic risk factors.

\section{Glucocorticoid signalling in cardio- vascular organs}

Both GR and MR are expressed widely in the cardiovascular system, including in the vessel wall and myocardium (reviewed in (14-16)). GRs are also present in inflammatory cells, which invade vascular lesions, notably in macrophages (66). We have described 11ß-HSD1 in vascular smooth muscle and $11 \beta$-HSD2 in the endothelium $(67,68)$, although this distribution may vary somewhat between species and between vascular sites $((69,70)$, reviewed in (16)). Low

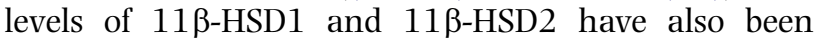
reported in rat and human heart $(67,71-75)$ and $11 \beta$ HSD1 is expressed in differentiated macrophages (76, 77). On the balance of the evidence, with reference to the model in Fig. 1, myocardial cells may follow Fig. 1A, 
Table 2 Cardiovascular effects of glucocorticoids.

\begin{tabular}{|c|c|c|}
\hline Site of action & Via glucocorticoid receptors & Via mineralocorticoid receptors \\
\hline Vascular smooth muscle & $\begin{array}{l}\uparrow \text { contractility e.g. to noradrenaline (185) } \\
\downarrow \text { proliferation (138-140) } \\
\downarrow \text { migration (141) }\end{array}$ & $\begin{array}{l}\uparrow \text { perivascular inflammation (186) } \\
\uparrow \text { vasoconstriction (153) }\end{array}$ \\
\hline Endothelial cell & $\begin{array}{l}\downarrow \text { endothelium-dependent vasodilatation (160) } \\
\downarrow \text { angiogenesis }(86,134)\end{array}$ & $\uparrow$ vasodilatation (153) \\
\hline Myocardium & & $\uparrow$ fibrosis $(133,187)$ \\
\hline Macrophage & $\begin{array}{l}\uparrow \text { cytokines }(188) \\
\uparrow \text { apoptosis }(189) \\
\downarrow \text { phagocytosis of apoptotic neutrophils (66) }\end{array}$ & \\
\hline Non-cardiovascular organs & $\begin{array}{l}\text { Obesity } \\
\text { Hypertension } \\
\text { Dyslipidaemia } \\
\text { Insulin resistance } \\
\text { Glucose intolerance } \\
\text { Prothrombotic }\end{array}$ & $\begin{array}{l}\text { Hypertension } \\
\text { Prothrombotic }\end{array}$ \\
\hline
\end{tabular}

Published data show effects of corticosteroids to: $\uparrow$, increase; $\downarrow$, decrease; or $\uparrow$, either increase or decrease.

vascular endothelial cells may follow Fig. 1B, vascular smooth muscle cells may follow Fig. 1C, and macrophages may follow Fig. 1C (but with only GR and not MR present). There have also been sporadic reports that vascular tissue and myocardium express the enzymes necessary for de novo steroidogenesis from cholesterol $(72,78,79)$, although the magnitude, if any, of this contribution appears to be very small.

The effects of glucocorticoids on cardiovascular tissues are summarised in Table 2, which shows diverse effects on vascular development, remodelling, tone and inflammation. There are substantial weaknesses in this field, however, since very few experiments have dissected systemic (e.g. actions in liver or kidney) from local (intravascular) effects of either glucocorticoids or mineralocorticoids, it has been difficult to recapitulate in vivo findings in experiments in isolated vessels in vitro, and the potential for occupancy of MR as well as GR by cortisol has not always been taken into account in interpretation of results.

The influence of $11 \beta$-HSDs on vascular function has been addressed using non-selective enzyme inhibitors (80-83), antisense knockdown (84) and in global 'knockout' mice $(68,85)$ but not yet by cell-specific manipulations of $11 \beta$-HSDs. While loss of $11 \beta$-HSD2 dehydrogenase inactivation of glucocorticoid in the endothelium was associated with enhanced vasoconstrictor responses, loss of $11 \beta$-HSD1 reductase regeneration of glucocorticoid in vascular smooth muscle did not influence vascular tone. More recent studies suggest that $11 \beta$-HSD1 influences remodelling responses in the vasculature (see below $(63,86)$ ). In vascular cells and macrophages in vitro, pro-inflammatory cytokines up-regulate $11 \beta$-HSD1 expression $(76,77,87)$, raising the intriguing possibility that local amplification of cortisol concentrations provides a counter-regulatory response which modifies remodelling during vascular injury or inflammation. However, in in vivo studies we were unable to confirm this phenomenon (88).

Against this background, the responses to glucocorticoids within the blood vessel wall will reflect the balance between access of ligands to MR and GR, between systemic versus local effects, and between other complex determinants of receptor interaction with gene transcription and 'non-genomic' signalling alluded to above. The role of glucocorticoids in the incidence and progression of cardiovascular disease is therefore unpredictable.

\section{Glucocorticoids and incidence of occlusive vascular disease}

\section{Exogenous anti-inflammatory glucocorticoids}

Despite their effects to induce cardiovascular risk factors, studies in animals have suggested that medium-term GR-agonist therapy is atheroprotective in mice (89) and rabbits $(90,91)$, as judged by markers such as aortic cholesterol content or cellular proliferation indices. Conversely, aldosterone reportedly increases, and MR antagonists decrease, atherogenesis in mice $(92,93)$. Further, glucocorticoid excess may promote calcification within arteriosclerotic lesions (94). In humans, a major concern has been that anti-inflammatory glucocorticoid therapy induces atherogenesis in patients with inflammatory diseases $(95,96)$. Indeed, there appears to be a dose-response relationship between cumulative exposure to glucocorticoids and the prevalence of carotid artery atheroma visualised by ultrasound amongst patients with rheumatoid arthritis (97). It has been difficult, however, to confidently dissect effects of glucocorticoids from those of the underlying inflammatory disease, which may itself be pro-atherogenic.

Glucocorticoid therapy for inflammatory disease was adopted before the era of randomised controlled trials 
(RCTs). Although some short-term RCTs have been conducted for example to assess efficacy of low-dose glucocorticoids as disease modifiers in early rheumatoid arthritis (98), it seems certain that RCTs will never be conducted which have sufficient statistical power and duration of exposure to detect effects of glucocorticoids on cardiovascular events. It would be considered unethical to withhold glucocorticoid therapy from patients with inflammatory disease, and unethical to expose patients who do not need anti-inflammatory therapy to the known adverse effects of glucocorticoids (fractures, hyperglycaemia, etc.) (98). In the absence of RCTs, the next best approach is by pharmacoepidemiology. Since glucocorticoids are one of the most commonly prescribed classes of drugs, they lend themselves to this approach. We have conducted two studies to examine the relationship between glucocorticoid therapy and cardiovascular events, making use of the data collected in the universal National Health Service in the UK $(99,100)$.

The first study was conducted using a case-control design comparing $>50000$ patients with cardiovascular disease and the same number of matched controls in the General Practice Research Database in England (99). In order for data to be collected, participants needed to be in contact with their primary care physician (general practitioner). For this reason, the study was conducted amongst patients who were all receiving glucocorticoid therapy of some kind, and the analysis compared doses of glucocorticoids received in the two groups. The odds ratio for use of oral glucocorticoid therapy (rather than topical or inhaled glucocorticoid therapy) in the group with cardiovascular disease was 1.31 (95\% confidence intervals 1.21-1.29).

The second study was conducted using a populationbased cohort design in $>150000$ residents of the Tayside region in Scotland (100) for whom data were collected in the Medicines Monitoring Unit for all drugs prescribed (which are identifiable because all pharmacy dispensing is recorded) and for morbidity and mortality from a variety of integrated databases. The rate of incident cardiovascular disease was $\sim 17 / 1000$ patientyears in subjects not exposed to glucocorticoids but rose to $\sim 24 / 1000$ patient-years in subjects treated with glucocorticoids by any route. Once adjusted for confounders (Fig. 3), the excess cardiovascular risk was entirely attributable to the relatively small group ( $\sim 2 \%$ of the population) exposed to supraphysiological doses of glucocorticoids ( $>7.5 \mathrm{mg}$ prednisolone or its equivalent each day), in whom the adjusted relative risk of cardiovascular events was 2.56 (2.18-2.99).

Although the primary end point of these studies was the occurrence of any cardiovascular event, we also examined rates of different events. Notably, glucocorticoids were most strongly associated with occurrence of heart failure and least strongly with cerebrovascular disease events $(99,100)$. This finding is consistent with the suggestion that glucocorticoids impair recovery from ischaemic

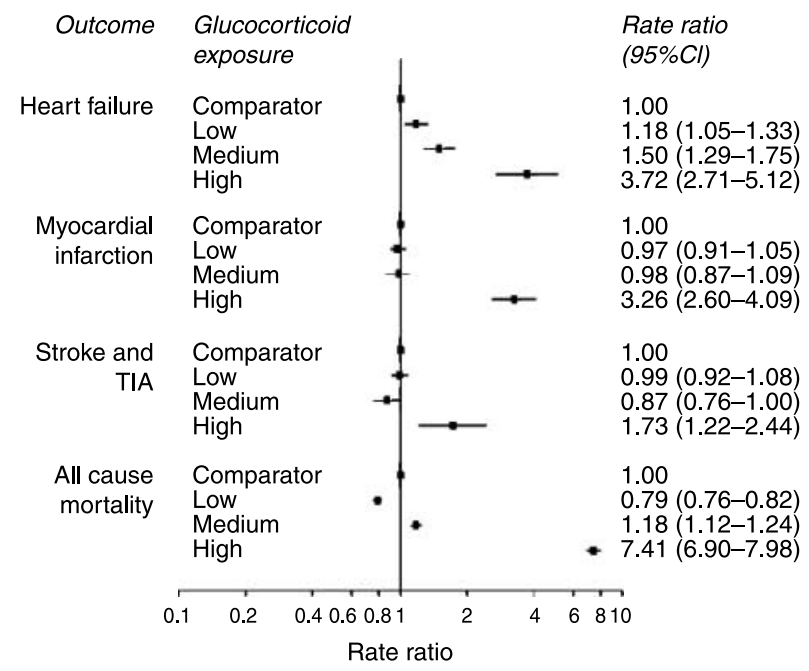

Figure 3 Cardiovascular disease risk in patients receiving antiinflammatory glucocorticoid therapy. In a population-based cohort study, the incidence of cardiovascular events was recorded in 68781 adults $>40$ years old receiving therapy with glucocorticoids and 82202 adults not receiving glucocorticoids during a 4-year follow-up period. Daily glucocorticoid dose was quantified as low (inhaled, nasal and topical steroid only), medium (oral, rectal or parenteral doses $<7.5 \mathrm{mg}$ prednisolone equivalent per day) or high ( $\geq 7.5 \mathrm{mg}$ prednisolone equivalent per day). The rate ratio is shown after adjustment for age, sex, social deprivation, diabetes mellitus, use of cardiovascular drugs, non-cardiovascular hospitalisation, cancer, renal disease and use of anti-rheumatic and bronchodilator therapy. Reproduced with permission from (100). TIA, transient ischaemic attack.

events, for example by inhibiting collateral angiogenesis and/or by increasing myocardial fibrosis (see below).

The greatest limitation of the pharmacoepidemiological approach is 'confounding by indication', i.e. the possibility that the risk is attributable to the underlying disease being treated rather than to the use of glucocorticoids. In both of our studies $(99,100)$, effects were consistent across different disease indications. Adjustment for smoking did not substantially attenuate the effect of glucocorticoids. However, in other studies involving cohorts of patients with rheumatoid arthritis, there is some evidence of interactions between effects of glucocorticoids and the underlying inflammatory disease on cardiovascular risk. In a Canadian cohort of $>40000$ subjects, no excess risk of heart failure with glucocorticoid exposure was identified (101). In a smaller US cohort, a dose-dependent risk of cardiovascular disease with glucocorticoid exposure was confirmed, but was only detectable amongst rheumatoid factor-positive patients (102). Studies in other disease groups have probably been too small to be confident of their findings. For example, in one cohort $(n=136)$ of polymyalgia/giant cell arteritis patients, glucocorticoid therapy predicted increased cardiovascular risk (103), but in another cohort $(n=364)$ this effect was not seen (104).

Intriguingly, adjustment for the presence of components of the metabolic syndrome (hypertension, diabetes mellitus and dyslipidaemia) did not eliminate 
the effect of glucocorticoids $(99,100,103)$, raising the possibility that the influence of glucocorticoids on cardiovascular outcome is not mediated exclusively by known cardiovascular risk factors and might be aggravated by actions in the blood vessel wall.

\section{Exogenous glucocorticoid replacement therapy}

Although representing a small minority of patients being treated with glucocorticoids, in endocrinology practice we are concerned with patients with hypopituitarism or adrenocortical failure receiving replacement doses of glucocorticoids. The most commonly used steroids for replacement therapy are cortisol (hydrocortisone) or the pre-hormone cortisone (which is 'activated' to cortisol by $11 \beta$-HSD1 on first pass through the liver). Notably, replacement therapy usually involves non-selective GR/MR agonists (cortisol), by contrast with antiinflammatory therapy, which usually involves selective GR agonists (prednisolone, etc). The pharmacokinetics of cortisol, which has high bioavailability and a short halflife ( $\sim 90 \mathrm{~min})$, makes it impossible to replicate physiological circulating cortisol levels (105), especially since the normal peak of circulating cortisol occurs in advance of waking each morning. In order to achieve sufficiently prolonged effects after each dose, without excessively frequent daily dosing, most patients take doses that induce a supraphysiological level for the first hour or two after dosing. There is evidence from measurement of total cortisol metabolite excretion in urine that these 'standard' daily doses are supraphysiological (106), and indeed there is a dose-dependent risk of associated cardiovascular risk factors including obesity and dyslipidaemia (107). By comparison with 'reference' values in the population, cardiovascular event rates are reported to be higher in patients with hypopituitarism (108-111) and adrenocortical insufficiency (112). Although there may be several endocrine factors at play, it is plausible to attribute this excess to supraphysiological glucocorticoid therapy.

\section{Endogenous glucocorticoids}

As described previously, many studies have reported associations between dysfunction of the HPA axis and risk factors for cardiovascular disease in the population. However, data are only now emerging concerning associations between the HPA axis and the occurrence of atheromatous disease. These studies are hampered by the lack of simple measures of HPA axis function which can be applied in large epidemiological studies. Most investigators have relied on fasting plasma cortisol levels, a crude index of HPA axis function. In the Caerphilly Heart Study, Davey-Smith et al. (113) reported a positive association between the plasma cortisol/testosterone ratio and incident vascular disease; cortisol alone was not an independent predictor. In smaller studies, higher plasma cortisol has also been associated with the extent of atheromatous disease quantified by coronary angiography (114), and predicted mortality in patients with heart failure (115). Polymorphisms in the GR gene have recently been associated with cardiovascular event rate in populationbased studies in Rotterdam (SWJ Lamberts, personal communication) and Sydney (116) (Table 1).

In spontaneous Cushing's syndrome, few investigators have accumulated sufficient numbers of patients to generate meaningful data on cardiovascular events. However, intermediate markers, such as carotid intimamedia thickness, are abnormal in these patients (117) even after the removal of the tumour responsible for glucocorticoid excess (118).

\section{Reducing glucocorticoid action and atheroprotection}

Given the association of elevated glucocorticoid action with obesity, cardiovascular risk factors and occlusive vascular disease events, it seems attractive to seek to reduce glucocorticoid action in order to prevent cardiovascular disease. It appears that simultaneous reduction of both GR and MR activation by glucocorticoids has most to offer (Table 2). With respect to reducing GR-dependent signalling, the challenge has been to reduce glucocorticoid action selectively in the blood vessel wall and/or in metabolically important tissues such as liver and adipose tissue, without: i) impairing negative feedback control of the HPA axis, producing compensatory hypercortisolaemia; ii) reducing glucocorticoid action in immune cells, producing a pro-inflammatory state; or iii) preventing an effective cortisol response during stress. Agents that inhibit cortisol biosynthesis or antagonise ligand binding to GR $(119,120)$ are likely to fall at one of these hurdles. However, inhibition of the cortisolgenerating enzyme $11 \beta$-HSD1 may be safe and successful $(4,61)$. Since the enzyme is predominantly expressed in liver and adipose tissue and is also present in vascular smooth muscle, inhibitors may have disproportionately greater effects on metabolism and cardiovascular disease progression than on the HPA axis and the immune system. Moreover, during stress, although 11 $\beta$-HSD1 inhibitors will reduce the component of intracellular cortisol derived from local regeneration, they should not prevent 'flooding' of the cell by cortisol from the circulation during significant hypercortisolaemia.

Selective 11 $\beta$-HSD1 inhibitors have recently been developed and tested in rodents (62-65). In models of obesity and type 2 diabetes, they improve blood glucose, dyslipidaemia, hepatic steatosis, central obesity and insulin sensitivity. Most importantly, in ApoE-deficient mice 11 $\beta$-HSD1 inhibition produces very striking protection from aortic cholesterol accumulation on Western high-fat diet, which was disproportionate to the improvement in serum lipid profile, suggesting a potent atheroprotective effect potentially mediated in the 
blood vessel wall (63). 11ß-HSD inhibitors are now being evaluated in early clinical trials.

\section{Glucocorticoids and outcomes from occlusive vascular disease}

The role of glucocorticoids in occlusive cardiovascular disease may not be limited to promoting the development and progression of atheroma. Glucocorticoids may also influence the outcomes after plaque rupture, thrombotic occlusion and other vascular injury.

\section{Recovery from myocardial infarction}

Given their anti-inflammatory effects, glucocorticoids have been proposed to be useful in reducing tissue damage after myocardial infarction (122). However, as noted above, the mechanisms of glucocorticoid action are complex. On one hand, acute induction of endothelial nitric oxide synthase, putatively through 'non-genomic' effects of GR, may be protective after both myocardial infarction (123) and cerebral ischaemia (124) in mice. Similarly, glucocorticoids may reduce tissue damage during cardiopulmonary bypass (125), coronary ischaemia (126) and renal ischaemia (127). On the other hand, glucocorticoids may limit tetrahydrobiopterin availability as cofactor for nitric oxide synthesis (128), potentially promoting synthesis of damaging reactive oxygen species rather than protective nitric oxide $(129,130)$. Glucocorticoids may also adversely influence longer term remodelling of the myocardium following infarction. MR-mediated fibrosis in the myocardium has received a great deal of attention since the randomised Aldactone evaluation study (RALES) and Eplerenone post acute myocardial infarction heart failure efficacy and survival study (EPHESUS) studies demonstrated the benefits of MR antagonists in patients with heart failure $(131,132)$. Although $11 \beta$ HSD2 has been described in human heart (72-75), its cellular distribution and magnitude of activity remain uncertain: it is likely to be insufficient to exclude cortisol from access to MR. Therefore, it may be cortisol rather than aldosterone which occupies MR in the myocardium (Fig. 1A) and influences fibrotic responses (133). In addition, GR activation prevents angiogenesis $(86,134,135)$, a key process in the recovery from infarction which ensures collateral circulation and reperfusion. Administration of glucocorticoids beyond the first few days after infarction might be predicted to impair reperfusion.

A number of clinical trials have been undertaken to test the effects of glucocorticoids administered in the first few days after myocardial infarction. Most of these were conducted in the 1970s with suboptimal methodology, but a recent meta-analysis suggests a small beneficial effect on mortality (136). The increased incidence of heart failure amongst glucocorticoid users in the pharmacoepidemiology studies described above $(99,100,137)$, however, raises the possibility that longer term glucocorticoid therapy has an adverse effect on vascular remodelling.

While anti-angiogenic therapy may have a role in oncology and in treating ischaemic retinopathies, proangiogenic therapy has been sought to improve collateral revascularisation following ischaemia and infarction. Since glucocorticoids inhibit angiogenesis and 11ß-HSD1 regenerates glucocorticoids within blood vessels, we recently tested the hypothesis that loss of 11 $\beta$-HSD1 would enhance angiogenesis (86). We found that 11ß-HSD1 null mice exhibit enhanced angiogenesis in isolated aortic rings, in sponges inserted subcutaneously, in surgical wounds, and in the myocardium following coronary artery ligation and myocardial infarction. This was associated with improved recovery from infarction as judged by left ventricular ejection fraction (Fig. 4).

\section{Recovery from intravascular injury}

One of the reasons for improved survival from cardiovascular disease is the advent of intravascular
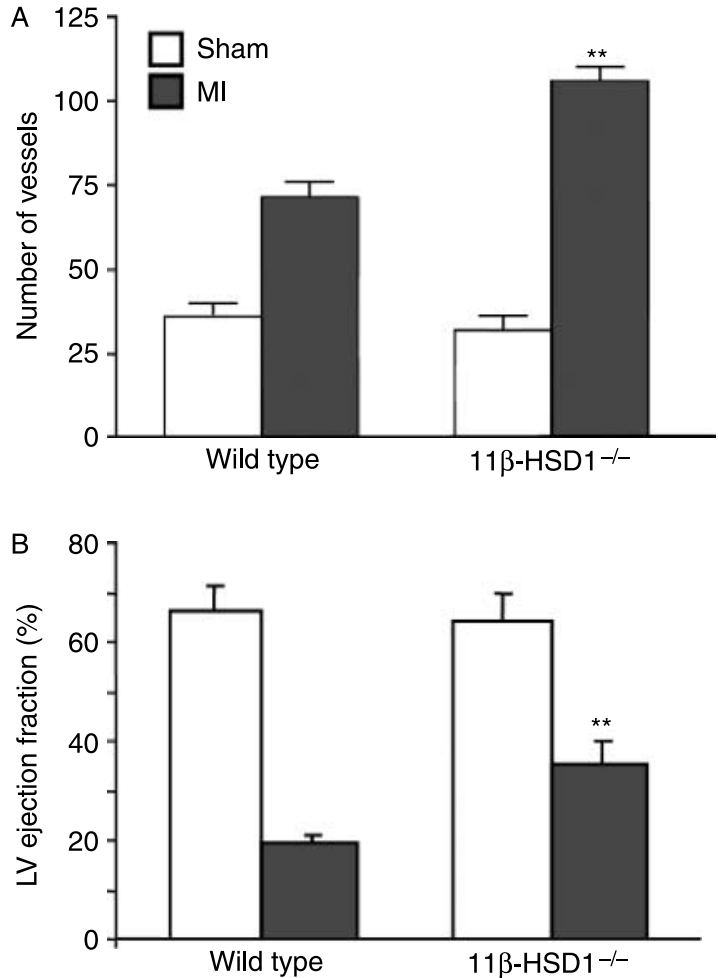

Figure 4 Amplification of myocardial angiogenesis and protection from left ventricular dysfunction in $11 \beta-H S D 1^{-1-}$ null mice. Mice were studied 7 days after coronary artery ligation to induce a myocardial infarction ( $\mathrm{Ml}$, shaded bars) or sham surgery (open bars). (A) Myocardial vessels were identified at light microscopy in vitro by von Willebrand factor immunohistochemistry. (B) Left ventricular ejection fraction was quantified by transthoracic echocardiography in vivo. $11 \beta$-HSD $1^{-1-}$ null mice had increased angiogenesis and were protected from left ventricular dysfunction induced by coronary artery ligation. ${ }^{\star \star} P<0.01$ versus wild type. Adapted from (86). 
interventions, including balloon angioplasty (1). A major limiting factor following such procedures, however, is the occurrence of early restenosis in which vascular smooth muscle neo-intimal proliferation is prominent. Similar pathological processes may also be relevant in the spontaneous formation of occlusive plaques. On the basis that glucocorticoids are antiinflammatory and have anti-proliferative (138-140) and anti-migratory (141) effects on smooth muscle cells, they have been employed to prevent restenosis (16, 142). Systemic administration was effective in many animal models (reviewed in (16)). However, in clinical trials, glucocorticoids have been successful in some (143-146) but not all (147-151) studies. A likely explanation for discrepant results is that the benefits of local anti-inflammatory effects in the injured blood vessel are offset by adverse systemic effects. Alternatively, the observation that MR antagonists also reduce neo-intimal lesion formation (152) suggests that the anti-inflammatory effects of GR activation may be offset by pro-inflammatory MR activation (153). To overcome these limitations, glucocorticoid-eluting stents have been proposed to deliver local antiinflammatory therapy (154-156) using glucocorticoids devoid of affinity for MR, such as dexamethasone and prednisolone (7). However, there remains the risk that GR may induce changes within the vessel which offset any benefit of conventional anti-inflammatory effects, for example by increasing local angiotensin II (157, 158 ) or endothelin-1 (159) generation or by decreasing endothelial nitric oxide generation (160).

\section{Conclusions}

The evidence reviewed above suggests that glucocorticoid excess not only induces cardiovascular risk factors, but also hastens the incidence and progression of atheromatous vascular disease. This probably reflects the combined effects of systemic and local vascular actions of glucocorticoids. Systemic effects are mediated through GR activation in liver, adipose tissue, pancreas and muscle; MR activation in kidney may also be involved in people with impaired 11 $\beta$-HSD2 activity. Local effects in the blood vessel wall and myocardium are mediated by both GR and MR and modified in a cellspecific pattern by $11 \beta$-HSD1 and $11 \beta$-HSD2. These local effects may influence not only atherogenesis but also the outcomes of vascular occlusion and injury. They may be both protective (preventing neointimal proliferation via GR) and adverse (preventing angiogenesis via GR and promoting perivascular inflammation and myocardial fibrosis via MR). It is probable that cortisol is the principal ligand occupying MR in cardiovascular tissues, so that the focus on the renin-angiotensin-aldosterone axis in interpreting the clinical benefits of MR antagonists is arguably misplaced. In addition to MR antagonism, inhibition of $11 \beta$-HSD1 provides a route to prevent both
MR and GR activation in many tissues including liver, adipose tissue and vascular smooth muscle. The net effect of $11 \beta$-HSD1 inhibition appears to be atheroprotective and beneficial after myocardial infarction in mice. These findings offer the promise of therapeutic potential for tissue-specific manipulation of glucocorticoid action in the prevention and treatment of cardiovascular disease in humans.

\section{Acknowledgements}

Our research is funded predominantly by the British Heart Foundation and the Wellcome Trust. The author is grateful to many co-authors, colleagues and collaborators for their invaluable contributions.

\section{Disclosure}

Within the past 2 years, B R W has consulted for AstraZeneca, Dainippon Sumitomo, Merck, Johnson \& Johnson, Incyte, Ipsen, Roche, Vitae, Zydus Research Centre and received lecture fees from Abbott and Bristol Myers Squibb. B R W is an inventor on relevant patents held by University of Edinburgh.

\section{References}

1 Fox FA, Steg PG, Eagle KA, Goodman SG, Anderson FA, Jr, Granger CB, Flather MD, Budaj A, Quill A \& Gore JM. Decline in rates of death and heart failure in acute coronary syndromes, 1999-2006. Journal of the American Medical Association 2007 297 1892-1900.

2 Sapolsky RM, Romero LM \& Munck AU. How do glucocorticoids influence stress responses? Integrating permissive, suppressive, stimulatory, and preparative actions Endocrine Reviews 200021 55-89.

3 Stewart PM \& Krozowski ZS. 11Beta hydroxysteroid dehydrogenase. Vitamins and Hormones 199957 249-324.

4 Seckl JR \& Walker BR. 11 $\beta$-Hydroxysteroid dehydrogenase type 1 - a tissue-specific amplifier of glucocorticoid action. Endocrinology $20011421371-1376$.

5 Tomlinson JW, Walker EA, Bujalska IJ, Draper N, Lavery GG, Cooper MS, Hewison M \& Stewart PM. 11 $\beta$-Hydroxysteroid dehydrogenase type 1: a tissue-specific regulator of glucocorticoid response. Endocrine Reviews 200425 831-866.

6 Tasker JG, Di S \& Malcher-Lopes R. Minireview: rapid glucocorticoid signaling via membrane-associated receptors. Endocrinology $2006 \mathbf{1 4 7} 5549-5556$.

7 Diederich S, Scholz T, Eigendorff E, Bumke-Vogt C, Quinkler M, Exner P, Pfeiffer AF, Oelkers W \& Bahr V. Pharmacodynamics and pharmacokinetics of synthetic mineralocorticoids and glucocorticoids: receptor transactivation and prereceptor metabolism by 11 beta-hydroxysteroid-dehydrogenases. Hormone Metabolic Research 200436 423-429.

8 Best R, Nelson SM \& Walker BR. Dexamethasone and 11-dehydrodexamethasone as tools to investigate the isozymes of $11 \beta$ hydroxysteroid dehydrogenase in vitro and in vivo. Journal of Endocrinology 1997153 41-48.

9 Dallman MF, Strack AM, Akana SF, Bradbury MJ, Hanson ES, Scribner KA \& Smith M. Feast and famine: critical role of glucocorticoids with insulin in daily energy flow. Frontiers in Neuroendocrinology 199314 303-347. 
10 Andrews RC \& Walker BR. Glucocorticoids and insulin resistance: old hormones, new targets. Clinical Science 199996 513-523.

11 Walker BR. Extra-adrenal regeneration of glucocorticoids by 11 beta-hydroxysteroid dehydrogenase type 1: physiological regulator and pharmacological target for energy partitioning. Proceedings of the Nutrition Society 200766 1-8.

12 Whitworth JA. Studies on the mechanism of glucocorticoid hypertension in humans. Blood Pressure 19943 24-32.

13 Whitworth JA, Mangos GJ \& Kelly JJ. Cushing, cortisol and cardiovascular disease. Hypertension 200036 912-916.

14 Walker BR \& Williams BC. Corticosteroids and vascular tone: mapping the messenger maze. Clinical Science $1992 \mathbf{8 2}$ 597-605.

15 Ullian ME. The role of corticosteroids in the regulation of vascular tone. Cardiovascular Research 199941 55-64.

16 Hadoke PWF, Macdonald L, Logie JJ, Small GR, Dover AR \& Walker BR. Intravascular glucocorticoid metabolism as a modulator of vascular structure and function. Cellular and Molecular Life Sciences 200663 565-578.

17 Dallman MF, la Fleur SE, Pecoraro NC, Gomez F, Houshyar H \& Akana SE. Minireview: glucocorticoids - food intake, abdominal obesity, and wealthy nations in 2004. Endocrinology 2004145 2633-2638.

18 Sapolsky RM, Krey LC \& McEwen BS. The neuroendocrinology of stress and ageing. The glucocorticoid cascade hypothesis. Endocrine Reviews 19867 284-301.

19 Bjorntorp P, Holm G \& Rosmond R. Hypothalamic arousal, insulin resistance and type 2 diabetes mellitus. Diabetic Medicine $199916373-381$.

20 Walker BR. Cortisol - cause and cure for metabolic syndrome? Diabetic Medicine 200623 1281-1288.

21 Walker BR, Soderberg S, Lindahl B \& Olsson T. Independent effects of obesity and cortisol in predicting cardiovascular risk factors in men and women. Journal of Internal Medicine $2000 \mathbf{2 4 7}$ 198-204.

22 Reynolds RM, Syddall HE, Walker BR, Wood PJ \& Phillips DIW. Predicting cardiovascular risk factors from plasma cortisol measured during oral glucose tolerance tests. Metabolism: Clinical and Experimental 200352 524-527.

23 Bjorntorp P. Visceral fat accumulation: the missing link between psychosocial factors and cardiovascular disease? Journal of Internal Medicine 1991230 195-201.

24 Rosmond R, Dallman MF \& Bjorntorp P. Stress-related cortisol secretion in men: relationships with abdominal obesity and endocrine, metabolic and haemodynamic abnormalities. Journal of Clinical Endocrinology and Metabolism $1998 \mathbf{8 3}$ 1853-1859.

25 Brunner EJ, Hemingway H, Walker BR, Page M, Clarke P, Juneja M, Shipley MJ, Kumari M, Andrew R, Seckl JR, Papadopoulos A, Checkley S, Rumley A, Lowe GDO, Stansfield SA \& Marmot MG. Adrenocortical, autonomic and inflammatory causes of the metabolic syndrome: nested casecontrol study. Circulation 2002106 2659-2665.

26 Phillips DIW, Barker DJP, Fall CHD, Whorwood CB, Seckl JR, Wood PJ \& Walker BR. Elevated plasma cortisol concentrations: an explanation for the relationship between low birthweight and adult cardiovascular risk factors. Journal of Clinical Endocrinology and Metabolism 199883 757-760.

27 Phillips DIW, Walker BR, Reynolds RM, Flanagan DEH, Wood PJ, Osmond C, Barker DJP \& Whorwood CB. Low birthweight and elevated plasma cortisol concentrations in adults from three populations. Hypertension 200035 1301-1306.

28 Reynolds RM, Walker BR, Phillips DIW, Sydall HE, Andrew R, Wood PJ \& Whorwood CB. Altered control of cortisol secretion in adult men with low birthweight and cardiovascular risk factors. Journal of Clinical Endocrinology and Metabolism 200186 245-250.

29 de Rooij SR, Painter RC, Phillips DI, Osmond C, Tanck MW, Bossuyt PM \& Roseboom TJ. Cortisol responses to psychological stress in adults after prenatal exposure to the Dutch famine. Psychoneuroendocrinology 200631 1257-1265.
30 Jones A, Godfrey KM, Wood P, Osmond C, Goulden P \& Phillips DI. Fetal growth and the adrenocortical response to psychological stress. Journal of Clinical Endocrinology and Metabolism 200691 1868-1871.

31 Reynolds RM, Godfrey KM, Barker M, Osmond C \& Phillips DI. Stress responsiveness in adult life: influence of mother's diet in late pregnancy. Journal of Clinical Endocrinology and Metabolism 200792 2208-2210.

32 Seckl JR. Prenatal glucocorticoids and long-term programming. European Journal of Endocrinology 2004151 49-62.

33 Weaver IC, Cervoni N, Champagne FA, D'Alessio AC, Sharma S, Seckl JR, Dymov S, Szyf M \& Meaney MJ. Epigenetic programming by maternal behavior. Nature Neuroscience 20047 847-854.

34 Walker BR, Best R, Shackleton CHL, Padfield PL \& Edwards CRW. Increased vasoconstrictor sensitivity to glucocorticoids in essential hypertension. Hypertension 199627 190-196.

35 Walker BR, Phillips DIW, Noon JP, Panarelli M, Best R, Edwards HE, Holton DW, Seckl JR, Webb DJ \& Watt GCM. Increased glucocorticoid activity in men with cardiovascular risk factors. Hypertension 199831 891-895.

36 Panarelli M, Holloway CD, Fraser R, Connell JMC, Ingram MC, Anderson NH \& Kenyon CJ. Glucocorticoid receptor polymorphism, skin vasoconstriction, and other metabolic intermediate phenotypes in normal human subjects. Journal of Clinical Endocrinology and Metabolism $1998 \mathbf{8 3}$ 1846-1852.

37 Andrews RC, Herlihy O, Livingstone DEW, Andrew R \& Walker BR. Abnormal cortisol metabolism and tissue sensitivity to cortisol in patients with glucose intolerance. Journal of Clinical Endocrinology and Metabolism 200287 5587-5593.

38 Reynolds RM, McKeigue PM, Lithell HO, Chapman KE, Seckl JR \& Walker BR. Increased glucocorticoid receptor expression in skeletal muscle of men with cardiovascular risk factors. Journal of the American Medical Association 2002287 2505-2506.

39 Whorwood CB, Donovan SJ, Flanagan D, Phillips DIW \& Byrne CD. Increased glucocorticoid receptor expression in human skeletal muscle cells may contribute to the pathogenesis of the metabolic syndrome. Diabetes 200251 1066-1075.

40 Wake DJ, Rask E, Livingstone DEW, Soderberg S, Olsson T \& Walker BR. Local and systemic impact of transcriptional upregulation of $11 \beta$-hydroxysteroid dehydrogenase type 1 in adipose tissue in human obesity. Journal of Clinical Endocrinology and Metabolism 200388 2983-2988.

41 van Rossum EF \& Lamberts SW. Polymorphisms in the glucocorticoid receptor gene and their associations with metabolic parameters and body composition. Recent Progress in Hormone Research 200459 333-357.

42 Stratakis CA, Karl M, Schulte HM \& Chrousos GP. Glucocorticosteroid resistance in humans - elucidation of the molecular mechanisms and implications for pathophysiology. Annals of the New York Academy of Sciences 1994746 362-376.

43 Lamberts SWJ, Koper JW \& de Jong FH. Familial and iatrogenic cortisol receptor resistance. Journal of Steroid Biochemistry and Molecular Biology 199243 385-388.

44 van den Akker EL, Russcher H, van Rossum EF, Brinkmann AO, de Jong FH, Hokken A, Pols HA, Koper JW \& Lamberts SW. Glucocorticoid receptor polymorphism affects transrepression but not transactivation. Journal of Clinical Endocrinology and Metabolism $2006912800-2803$.

45 Harris HJ, Kotelevtsev YV, Mullins JJ, Seckl JR \& Holmes MC. 11 $\beta$ Hydroxysteroid dehydrogenase type 1 null mice have altered hypothalamic-pituitary-adrenal axis activity: a novel control of glucocorticoid feedback. Endocrinology 2001142 114-120.

46 Walker BR, Stewart PM, Shackleton CHL, Padfield PL \& Edwards CRW. Deficient inactivation of cortisol by $11 \beta-$ hydroxysteroid dehydrogenase in essential hypertension. Clinical Endocrinology $199339221-227$.

47 Soro A, Ingram MC, Tonolo G, Glorioso N \& Fraser R. Evidence of coexisting changes in 11ß-hydroxysteroid dehydrogenase and $5 \beta$-reductase activity in patients with untreated essential hypertension. Hypertension 199525 67-70. 
48 Lovati E, Ferrari P, Dick B, Jostarndt K, Frey BM, Frey FJ, Schorr U \& Sharma AM. Molecular basis of human salt sensitivity: the role of the 11ß-hydroxysteroid dehydrogenase type 2. Journal of Clinical Endocrinology and Metabolism 199984 3745-3749.

49 Rask E, Olsson T, Soderberg S, Andrew R, Livingstone DEW, Johnson O \& Walker BR. Tissue-specific dysregulation of cortisol metabolism in human obesity. Journal of Clinical Endocrinology and Metabolism 200186 1418-1421.

50 Rask E, Walker BR, Soderberg S, Livingstone DEW, Eliasson M, Johnson O, Andrew R \& Olsson T. Tissue-specific changes in peripheral cortisol metabolism in obese women; increased adipose 11ß-hydroxysteroid dehydrogenase type 1 activity. Journal of Clinical Endocrinology and Metabolism $2002 \mathbf{8 7}$ 3330-3336.

51 Goedecke JH, Wake DJ, Levitt NS, Lambert EV, Collins MR, Morton NM, Seckl JR \& Walker BR. Glucocorticoid metabolism within superficial rather than visceral adipose tissues is associated with features of the metabolic syndrome in South African women. Clinical Endocrinology 200665 81-87.

52 Lindsay RS, Tataranni A, Permana P, Livingstone DEW, Wake DJ \& Walker BR. Subcutaneous adipose 11ß-hydroxysteroid dehydrogenase type 1 activity and mRNA levels are associated with adiposity and insulinaemia in Pima Indians and Caucasians. Journal of Clinical Endocrinology and Metabolism $2003 \mathbf{8 8}$ 2738-2744.

53 Kannisto K, Pietilainen KH, Ehrenborg E, Rissanen A, Kaprio J, Hamsten A \& Yki-Jarvinen H. Overexpression of 11 beta-hydroxy steroid dehydrogenase- 1 in adipose tissue is associated with acquired obesity and features of insulin resistance: studies in young adult monozygotic twins. Journal of Clinical Endocrinology and Metabolism 200489 4414-4421.

54 Paulmyer-Lacroix O, Boullu S, Oliver C, Alessi M-C \& Grino M. Expression of the mRNA coding for $11 \beta$-hydroxysteroid dehydrogenase type 1 in adipose tissue from obese patients: an in situ hybridization study. Journal of Clinical Endocrinology and Metabolism 200287 2701-2705.

55 Engeli S, Bohnke J, Feldpausch M, Gorzelniak K, Heintze U, Janke J, Luft FC \& Sharma AM. Regulation of $11 \beta$-hydroxysteroid dehydrogenase genes in human adipose tissue: influence of central obesity and weight loss. Obesity Research 200412 9-17.

56 Desbriere R, Vuaroqueaux V, Achard V, Boullu-Ciocca S, Labuhn M, Dutour A \& Grino M. 11ß-Hydroxysteroid dehydrogenase type 1 mRNA is increased in both visceral and subcutaneous adipose tissue of obese patients. Obesity $2006 \mathbf{1 4}$ 794-798.

57 Westerbacka J, Yki-Jarvinen H, Vehkavaara S, Hakkinen A-M, Andrew R, Wake DJ, Seckl JR \& Walker BR. Body fat distribution and cortisol metabolism in healthy men: enhanced $5 \beta$-reductase and lower cortisol/cortisone metabolite ratios in men with fatty liver. Journal of Clinical Endocrinology and Metabolism $2003 \mathbf{8 8}$ 4924-4931.

58 Michailidou Z, Jensen MD, Dumesic DA, Chapman KE, Seckl JR, Walker BR \& Morton NM. Omental 11 $\beta$-hydroxysteroid dehydrogenase 1 correlates with fat cell size independently of obesity. Obesity 200715 1155-1163.

59 Franks PW, Knowler WC, Nair S, Koska J, Lee Y-H, Lindsay RS, Walker BR, Looker HC, Permana PA, Tataranni PA \& Hanson RL. Interaction between an 11ßHSD1 gene variant and birth era modifies the risk of hypertension in Pima Indians. Hypertension 200444 681-688.

60 Nair S, Lee YH, Lindsay RS, Walker BR, Tataranni PA, Bogardus C, Baier LJ \& Permana PA. 11ß-Hydroxysteroid dehydrogenase type 1: genetic polymorphisms are associated with type 2 diabetes in Pima Indians independently of obesity and expression in adipocyte and muscle. Diabetologia $2004 \mathbf{4 7}$ 1088-1095.

61 Walker BR, Connacher AA, Lindsay RM, Webb DJ \& Edwards CRW. Carbenoxolone increases hepatic insulin sensitivity in man: a novel role for 11-oxosteroid reductase in enhancing glucocorticoid receptor activation. Journal of Clinical Endocrinology and Metabolism 199580 3155-3159.
62 Berthiaume M, Laplante M, Festuccia W, Gelinas Y, Poulin S, Lalonde J, Joanisse DR, Thieringer R \& Deshaies Y. Depot-specific modulation of rat intraabdominal adipose tissue lipid metabolism by pharmacological inhibition of 11 beta-hydroxysteroid dehydrogenase type 1. Endocrinology 2007148 2391-2397.

63 Hermanowski-Vosatka A, Balkovec JM, Cheng K, Chen HY, Hernandez M, Koo GC, Le Grand CB, Li Z, Metzger JM, Mundt SS, Noonan H, Nunes CN, Olson SH, Pikounis B, Ren N, Robertson N, Schaeffer JM, Shah K, Springer MS, Strack AM, Stowski M, Wu K, Wu T, Xiao J, Zhang BB, Wright SD \& Thieringer R. 11ß-HSD1 inhibition ameliorates metabolic syndrome and prevents progression of atherosclerosis in mice. Journal of Experimental Medicine 2005202 517-527.

64 Alberts P, Engblom L, Edling N, Forsgren M, Klingstrom G, Larsson C, Ronquist-Nii Y, Ohman B \& Abrahmsen L. Selective inhibition of 11beta-hydroxysteroid dehydrogenase type 1 decreases blood glucose concentrations in hyperglycaemic mice. Diabetologia 200245 1528-1532.

65 Alberts P, Nilsson C, Selen G, Engblom NHM, Norlin S, Klingstrom G, Larsson C, Forsgren M, Ashkzan M, Nilsson CE, Fiedler M, Bergqvist E, Ohman B, Bjorkstrand E \& Abrahmsen LB. Selective inhibition of $11 \beta$-hydroxysteroid dehydrogenase type 1 improves hepatic insulin sensitivity in hyperglycaemic mice strains. Endocrinology $2003 \mathbf{1 4 4} 4755-4762$.

66 Rossi A, Liu Y, Cousin JM, Dransfield I, Seckl JR, Haslett C \& Savill J. Glucocorticoiods promote non-phlogistic phagocyte clearance of apoptotic leucocytes. Journal of Immunology 1999 162 3639-3646.

67 Walker BR, Yau JL, Brett LP, Seckl JR, Monder C, Williams BC \& Edwards CRW. 11 $\beta$-Hydroxysteroid dehydrogenase in vascular smooth muscle and heart: implications for cardiovascular responses to glucocorticoids. Endocrinology $1991 \mathbf{1 2 9}$ 3305-3312.

68 Christy C, Hadoke PWF, Paterson JM, Mullins JJ, Seckl JR \& Walker BR. Glucocorticoid action in mouse aorta; localisation of $11 \beta$-hydroxysteroid dehydrogenase type 2 and effects on responses to glucocorticoids in vitro. Hypertension $2003 \mathbf{4 2}$ 580-587.

69 Brem AS, Bina RB, King TC \& Morris DJ. Localization of 211 beta$\mathrm{OH}$ steroid dehydrogenase isoforms in aortic endothelial cells. Hypertension 199831 459-462.

70 Smith RE, Little PJ, Maguire JA, Stein-Oakley AN \& Krozowski ZS. Vascular localization of the 11 beta-hydroxysteroid dehydrogenase type II enzyme. Clinical and Experimental Pharmacology and Physiology 199623 549-551.

71 Smith RE \& Krozowski ZS. 11ß-Hydroxysteroid dehydrogenase type 1 enzyme in the hearts of normotensive and spontaneously hypertensive rats. Clinical and Experimental Pharmacology and Physiology 199623 642-647.

72 Kayes-Wandover KM \& White PC. Steroidogenic enzyme gene expression in the human heart. Journal of Clinical Endocrinology and Metabolism 200085 2519-2525.

73 Slight SH, Ganjam VK, Gomez-Sanchez CE, Zhou M-Y \& Weber KT. High affinity $\mathrm{NAD}^{+}$-dependent 11 beta-hydroxysteroid dehydrogenase in the human heart. Journal of Molecular and Cellular Cardiology 199628 781-787.

74 Bonvalet JP, Alfaidy N, Farman N \& Lombes M. Aldosterone: intracellular receptors in human heart. European Heart Journal 199516 92-97.

75 Lombes M, Alfaidy N, Eugene E, Lessana A, Farman N \& Bonvalet J-P. Prerequisite for cardiac aldosterone action: mineralocorticoid receptor and 11beta-hydroxysteroid dehydrogenase in the human heart. Circulation 199592 175-182.

76 Thieringer R, Le Grand CB, Carbin L, Cai T-Q, Wong B \& Wright SD. 11ß-Hydroxysteroid dehydrogenase type 1 is induced in human monocytes upon differentiation to macrophages. Journal of Immunology 2001167 30-35.

77 Gilmour JS, Coutinho AE, Cailhier JF, Man TY, Clay M, Thomas G, Harris HJ, Mullins JJ, Seckl JR, Savill JS \& Chapman KE. Local amplification of glucocorticoids by 11 beta-hydroxysteroid 
dehydrogenase type 1 promotes macrophage phagocytosis of apoptotic leukocytes. Journal of Immunology $2006 \mathbf{1 7 6}$ 7605-7611.

78 Takeda Y, Miyamori I, Yoneda T, Iki K, Hatakeyama H, Blair IA, Hsieh FY \& Takeda R. Synthesis of corticosterone in the vascular wall. Endocrinology $19941352283-2286$.

79 Funder JW. Cardiac synthesis of aldosterone: going, going, gone...? Endocrinology $20041454793-4795$.

80 Teelucksingh S, Mackie ADR, Burt D, McIntyre MA, Brett L \& Edwards CRW. Potentiation of hydrocortisone activity in skin by glycyrrhetinic acid. Lancet 1990335 1060-1063.

81 Walker BR, Connacher AA, Webb DJ \& Edwards CRW. Glucocorticoids and blood pressure: a role for the cortisol/cortisone shuttle in the control of vascular tone in man. Clinical Science 199283 171-178.

82 Walker BR, Sang KS, Williams BC \& Edwards CRW. Direct and indirect effects of carbenoxolone on responses to glucocorticoids and noradrenaline in rat aorta. Journal of Hypertension 199412 33-39.

83 Brem AS, Bina RB, Hill N, Alia C \& Morris DJ. Effects of licorice derivatives on vascular smooth muscle function. Life Sciences $199760207-214$.

84 Souness GW, Brem AS \& Morris DJ. 11ß-Hydroxysteroid dehydrogenase antisense affects vascular contractile response and glucocorticoid metabolism. Steroids 200267 195-201.

85 Hadoke PWF, Christy C, Kotelevtsev YV, Williams BC, Kenyon CJ, Seckl JR, Mullins JJ \& Walker BR. Endothelial cell dysfunction in mice after transgenic knockout of type 2, but not type 1, 11 $\beta$-hydroxysteroid dehydrogenase. Circulation 2001 $1042832-2837$.

86 Small GR, Hadoke PWF, Sharif I, Dover AR, Armour D, Kenyon CJ, Gray GA \& Walker BR. Preventing regeneration of glucocorticoids by $11 \beta$-hydroxysteroid dehydrogenase type 1 enhances angiogenesis. PNAS 2005102 12165-12170.

87 Cai T-Q, Wong B, Mundt SS, Thieringer R \& Wright SD. Induction of $11 \beta$-hydroxysteroid dehydrogenase type 1 but not -2 in human aortic smooth muscle cells by inflammatory stimuli. Journal of Steroid Biochemistry and Molecular Biology 200177 117-122.

88 Dover AR, Hadoke PW, Macdonald LJ, Miller E, Newby DE \& Walker BR. Intravascular glucocorticoid metabolism during inflammation and injury in mice. Endocrinology $2007 \mathbf{1 4 8}$ 166-172.

89 Tauchi Y, Zushida L, Chono S, Sato J, Ito K \& Morimoto K. Effect of dexamethasone palmitate-low density lipoprotein complex on cholesterol ester accumulation in aorta of atherogenic model mice. Biological \& Pharmaceutical Bulletin $200124925-929$.

90 Cavallero C, Di TU, Mingazzini PL, Nicosia R, Pericoli MN, Sarti P, Spagnoli LG \& Villaschi S. Cell proliferation in the atherosclerotic plaques of cholesterol-fed rabbits. Part 3. Histological and radioautographic observations on glucocorticoids-treated rabbits. Atherosclerosis 197625 145-152.

91 Asai K, Funaki C, Hayashi T, Yamada K, Naito M, Kuzuya M, Yoshida F, Yoshimine N \& Kuzuya F. Dexamethasone-induced suppression of aortic atherosclerosis in cholesterol-fed rabbits. Possible mechanisms. Arteriosclerosis and Thrombosis 199313 892-899.

92 Keidar S, Kaplan M, Pavlotzky E, Coleman R, Hayek T, Hamoud S \& Aviram M. Aldosterone administration to mice stimulates macrophage NADPH oxidase and increases atherosclerosis development: a possible role for angiotensin-converting enzyme and the receptors for angiotensin II and aldosterone. Circulation $20041092213-2220$.

93 Keidar S, Hayek T, Kaplan M, Pavlotzky E, Hamoud S, Coleman R \& Aviram M. Effect of eplerenone, a selective aldosterone blocker, on blood pressure, serum and macrophage oxidative stress, and atherosclerosis in apolipoprotein E-deficient mice. Journal of Cardiovascular Pharmacology 200341 955-963.

94 Kirton JP, Wilkinson FL, Canfield AE \& Alexander MY. Dexamethasone downregulates calcification-inhibitor molecules and accelerates osteogenic differentiation of vascular pericytes: implications for vascular calcification. Circulation Research 200698 1264-1272.

95 Davis JM, III, Maradit-Kremers H \& Gabriel SE. Use of low-dose glucocorticoids and the risk of cardiovascular morbidity and mortality in rheumatoid arthritis: what is the true direction of effect? Journal of Rheumatology 200532 1856-1862.

96 Maxwell SRJ, Moots RJ \& Kendall MJ. Corticosteroids: do they damage the cardiovascular system? Postgraduate Medical Journal $199470863-870$.

97 Del RI, O'Leary DH, Haas RW \& Escalante A. Effect of glucocorticoids on the arteries in rheumatoid arthritis. Arthritis and Rheumatism $2004 \mathbf{5 0} 3813-3822$.

98 Da Silva JA, Jacobs JW, Kirwan JR, Boers M, Saag KG, Ines LB, de Koning EJ, Buttgereit F, Cutolo M, Capell H, Rau R \& Bijlsma JW. Safety of low dose glucocorticoid treatment in rheumatoid arthritis: published evidence and prospective trial data. Annals of the Rheumatic Diseases $200665285-293$.

99 Souverain PC, Berard A, van Staa TP, Cooper C, Leufkens HGM \& Walker BR. Use of oral glucocorticoids and risk of cardiovascular and cerebrovascular disease in a population-based case-control study. Heart $200490859-865$.

100 Wei L, MacDonald TM \& Walker BR. Taking glucocorticoids by prescription is associated with subsequent cardiovascular disease. Annals of Internal Medicine 2004141 764-770.

101 Bernatsky S, Hudson M \& Suissa S. Anti-rheumatic drug use and risk of hospitalization for congestive heart failure in rheumatoid arthritis. Rheumatology $2005 \mathbf{4 4} 677-680$.

102 Davis JM, III, Maradit KH, Crowson CS, Nicola PJ, Ballman KV, Therneau TM, Roger VL \& Gabriel SE. Glucocorticoids and cardiovascular events in rheumatoid arthritis: a populationbased cohort study. Arthritis and Rheumatism 200756 820-830.

103 Uddhammar A, Eriksson AL, Nystrom L, Stenling R \& RantapaaDahlqvist $S$. Increased mortality due to cardiovascular disease in patients with giant cell arteritis in northern Sweden. Journal of Rheumatology 200229 737-742.

104 Maradit KH, Reinalda MS, Crowson CS, Davis JM, III, Hunder GG \& Gabriel SE. Glucocorticoids and cardiovascular and cerebrovascular events in polymyalgia rheumatica. Arthritis and Rheumatism $2007 \mathbf{5 7} 279-286$.

105 Howlett TA. An assessment of optimal hydrocortisone replacement therapy. Clinical Endocrinology 199746 263-268.

106 Walker BR. Andrew R, MacLeod KM \& Padfield PL. Growth hormone replacement inhibits renal and hepatic 11ß-hydroxysteroid dehydrogenases in ACTH-deficient patients. Clinical Endocrinology $1998 \mathbf{4 9} 257-263$.

107 Filipsson H, Monson JP, Koltowska-Haggstrom M, Mattsson A \& Johannsson G. The impact of glucocorticoid replacement regimens on metabolic outcome and comorbidity in hypopituitary patients. Journal of Clinical Endocrinology and Metabolism 200691 3954-3961.

108 Bates AS, Van't Hoff W, Jones PJ \& Clayton RN. The effect of hypopituitarism on life expectancy. Journal of Clinical Endocrinology and Metabolism 199681 1169-1172.

109 Bulow B, Hagmar L, Mikoczy Z, Nordstrom CH \& Erfurth EM. Increased cerebrovascular mortality in patients with hypopituitarism. Clinical Endocrinology 199746 75-81.

110 Tomlinson JW, Holden N, Hills RK, Wheatley K, Clayton RN, Bates AS, Sheppard MC \& Stewart PM. Association between premature mortality and hypopituitarism. West Midlands Prospective Hypopituitary Study Group. Lancet $20013 \mathbf{3 5 7}$ 425-431.

111 Svensson J, Bengtsson BA, Rosen T, Oden A \& Johannsson G. Malignant disease and cardiovascular morbidity in hypopituitary adults with or without growth hormone replacement therapy. Journal of Clinical Endocrinology and Metabolism $2004 \mathbf{8 9}$ 3306-3312.

112 Bergthorsdottir R, Leonsson-Zachrisson M, Oden A \& Johannsson G. Premature mortality in patients with Addison's disease: a population-based study. Journal of Clinical Endocrinology and Metabolism 200691 4849-4853. 
113 Davey Smith G, Ben-Shlomo Y, Beswick A, Yarnell J, Lightman SL \& Elwood P. Cortisol, testosterone and coronary heart disease. Prospective evidence from the Caerphilly study. Circulation 2005 $112332-340$.

114 Alevizaki M, Cimponeriu A, Lekakis J, Papamichael C \& Chrousos GP. High anticipatory stress plasma cortisol levels and sensitivity to glucocorticoids predict severity of coronary artery disease in subjects undergoing coronary angiography. Metabolism 200756 222-226.

115 Guder G, Bauersachs J, Frantz S, Weismann D, Allolio B, Ertl G, Angermann CE \& Stork S. Complementary and incremental mortality risk prediction by cortisol and aldosterone in chronic heart failure. Circulation 2007115 1754-1761.

116 Lin RCY, Wang XL \& Morris BJ. Association of coronary artery disease with glucocorticoid receptor $\mathrm{N} 363 \mathrm{~S}$ variant. Hypertension $200341404-407$.

117 Faggiano A, Pivonello R, Spiezia S, De Martino MC, Filippella M, Di Somma C, Lombardi G \& Colao A. Cardiovascular risk factors and common carotid artery caliber and stiffness in patients with Cushing's disease during active disease and 1 year after disease remission. Journal of Clinical Endocrinology and Metabolism 2003 $882527-2533$.

118 Colao A, Pivonello R, Spiezia S, Faggiano A, Ferone D, Filipovsky J, Marzullo P, Cerbone G, Siciliana M \& Lombardi G. Persistence of increased cardiovascular risk in patients with Cushing's disease after five years of successful cure. Journal of Clinical Endocrinology and Metabolism 199984 2664-2672.

119 Ottosson M, Marin P, Karason K, Elander A \& Bjorntorp P. Blockade of the glucocorticoid receptor with RU 486: effects in vitro and in vivo on human adipose tissue lipoprotein lipase activity. Obesity Research 19953 233-240.

120 Gaillard RC, Poffet D, Riondel AM \& Saurat J-H. RU486 inhibits peripheral effects of glucocorticoids in humans. Journal of Clinical Endocrinology and Metabolism 198561 1009-1011.

121 Bujalska IJ, Kumar S \& Stewart PM. Does central obesity reflect 'Cushing's disease of the omentum'? Lancet $1997 \mathbf{3 4 9}$ 1210-1213.

122 Alisky JM. Dexamethasone could improve myocardial infarction outcomes and provide new therapeutic options for noninterventional patients. Medical Hypotheses 200667 53-56.

123 Hafezi-Moghadam A, Simoncini T, Yang Z, Limbourg FP, Plumier JC, Rebsamen MC, Hsieh CM, Chui DS, Thomas KL, Prorock AJ, Laubach VE, Moskowitz MA, French BA, Ley K \& Liao JK. Acute cardiovascular protective effects of corticosteroids are mediated by non-transcriptional activation of endothelial nitric oxide synthase. Nature Medicine 20028 473-479.

124 Limbourg FP, Huang Z, Plumier JC, Simoncini T, Fujioka M, Tuckermann J, Schutz G, Moskowitz MA \& Liao JK. Rapid nontranscriptional activation of endothelial nitric oxide synthase mediates increased cerebral blood flow and stroke protection by corticosteroids. Journal of Clinical Investigation $2002 \mathbf{1 1 0}$ 1729-1738.

125 Enc Y, Karaca P, Ayoglu U, Camur G, Kurc E \& Cicek S. The acute cardioprotective effect of glucocorticoid in myocardial ischemiareperfusion injury occurring during cardiopulmonary bypass. Heart and Vessels 200621 152-156.

126 Valen G, Kawakami T, Tahepold P, Dumitrescu A, Lowbeer C \& Vaage J. Glucocorticoid pretreatment protects cardiac function and induces cardiac heat shock protein 72 . American Journal of Physiology. Heart and Circulatory Physiology 2000279 H836-H843.

127 Baker RC, Armstrong MA, Young IS, McClean E, O'Rourke D, Campbell FC, D'Sa AA \& McBride WT. Methylprednisolone increases urinary nitrate concentrations and reduces subclinical renal injury during infrarenal aortic ischemia reperfusion. Annals of Surgery $2006 \mathbf{2 4 4} 821-826$.

128 Hattori Y, Akimoto K, Nakanishi N \& Kasai K. Glucocorticoid regulation of nitric oxide and tetrahydrobiopterin in a rat model of endotoxic shock. Biochemical and Biophysical Research Communications 1997240 298-303.
129 Skott O, Uhrenholt TR, Schjerning J, Hansen PB, Rasmussen LE \& Jensen BL. Rapid actions of aldosterone in vascular health and disease - friend or foe? Pharmacology and Therapeutics 2006111 495-507.

130 Kimura A, Roseto J, Suh KY \& Bing RJ. Dexamethasone on inducible nitric oxide synthase and nitrite/nitrate production in myocardial infarction. Proceedings of the Society for Experimental Biology and Medicine 1998219 138-143.

131 Pitt B, Remme W, Zannad F, Neaton J, Martinez F, Roniker B, Bittman R, Hurley S, Kleiman J \& Gatlin M. Eplerenone, a selective aldosterone blocker, in patients with left ventricular dysfunction after myocardial infarction. New England Journal of Medicine 2003348 1309-1321.

132 Pitt B, Zannad F, Remme WJ, Cody R, Castaigne A, Perez A, Palensky J \& Wittes J. The effect of spironolactone on morbidity and mortality in patients with severe heart failure. Randomized Aldactone Evaluation Study Investigators. New England Journal of Medicine 1999341 709-717.

133 Funder JW. RALES, EPHESUS and redox. Steroid Biochemistry and Molecular Biology 200593 121-125.

134 Folkman J \& Ingber DE. Angiostatic steroids. Method of discovery and mechanism of action. Annals of Surgery 1987206 374-383.

135 Crum R, Szabo S \& Folkman J. A new class of steroids inhibits angiogenesis in the presence of heparin or a heparin fragment. Science $19852301375-1378$.

136 Giugliano GR, Giugliano RP, Gibson CM \& Kuntz RE. Metaanalysis of corticosteroid treatment in acute myocardial infarction. American Journal of Cardiology 200391 1055-1059.

137 Wei L, MacDonald TM \& Walker BR. Taking glucocorticoids by prescription is associated with subsequent cardiovascular disease. Annals of Internal Medicine 2004141 764-770.

138 Longenecker JP, Kilty LA \& Johnson LK. Glucocorticoid influence on growth of vascular wall cells in culture. Journal of Cell Physiology 1982113 197-202.

139 Longenecker JP, Kilty LA \& Johnson LK. Glucocorticoid inhibition of vascular smooth muscle cell proliferation: influence of homologous extracellular matrix and serum mitogens. Journal of Cell Biology 198498 534-540.

140 Berk BC, Vallega G, Griendling KK, Gordon JB, Cragoe EJ, Canessa M \& Alexander RW. Effects of glucocorticoids on $\mathrm{Na} / \mathrm{H}$ exchange and growth in cultured vascular smooth muscle cells. Journal of Cell Physiology 1988137 391-401.

141 Goncharova EA, Billington CK, Irani C, Vorotnikov AV, Tkachuk VA, Penn RB, Krymskaya VP \& Panettieri RA. Cyclic AMP-mobilizing agents and glucocorticoids modulate human smooth muscle cell migration. American Journal of Respiratory Cell and Molecular Biology 200329 19-27.

142 Berk BC, Gordon JB \& Alexander RW. Pharmacologic roles of heparin and glucocorticoids to prevent restenosis after coronary angioplasty. Journal of the American College of Cardiology 199117 111B-117B.

143 Versaci F, Gaspardone A, Tomai F, Ribichini F, Russo P, Proietti I, Ghini AS, Ferrero V, Chiariello L, Gioffre PA, Romeo F \& Crea F. Immunosuppressive therapy for the prevention of restenosis after coronary artery stent implantation (IMPRESS study). Journal of the American College of Cardiology 200240 1935-1942.

144 Kakio T, Matsumori A, Ohashi N, Yamada T, Saito T, Kawamoto A, Taguchi A, Morita Y, Takahashi M \& Sasayama S. Hydrocortisone reduces restenosis after stenting of small coronary arteries. Journal of Interventional Cardiology 2004 17 295-300.

145 Kakio T, Matsumori A, Ohashi N, Yamada T, Nobuhara M, Saito T, Kawamoto A, Taguchi A, Morita Y, Takahashi M \& Sasayama S. The effect of hydrocortisone on reducing rates of restenosis and target lesion revascularization after coronary stenting less than $3 \mathrm{~mm}$ in stent diameter. Internal Medicine 2003 42 1084-1089.

146 Ferrero V, Ribichini F, Rognoni A, Marino P, Brunelleschi S \& Vassanelli C. Comparison of efficacy and safety of lower-dose to 
higher-dose oral prednisone after percutaneous coronary interventions (the IMPRESS-LD study). American Journal of Cardiology 200799 1082-1086.

147 Pepine CJ, Hirshfeld JW, Macdonald RG, Henderson MA, Bass TA, Goldberg S, Savage MP, Vetrovec G, Cowley M \& Taussig AS. A controlled trial of corticosteroids to prevent restenosis after coronary angioplasty. M-HEART Group. Circulation $1990 \mathbf{8 1}$ 1753-1761.

148 Lee CW, Chae JK, Lim HY, Hong MK, Kim JJ, Park SW \& Park SJ. Prospective randomized trial of corticosteroids for the prevention of restenosis after intracoronary stent implantation. American Heart Journal 1999138 60-63.

149 Stone GW, Rutherford BD, McConahay DR, Johnson WL, Giorgi LV, Ligon RW \& Hartzler GO. A randomized trial of corticosteroids for the prevention of restenosis in 102 patients undergoing repeat coronary angioplasty. Catheterization and Cardiovascular Diagnosis 198918 227-231.

150 Reimers B, Moussa I, Akiyama T, Kobayashi Y, Albeiro R, Di Francesco L, Di Mario C \& Colombo A. Persistent high restenosis after local intrawall delivery of long-acting steroids before coronary stent implantation. Journal of Invasive Cardiology 1998 10 323-331.

151 Rab ST, King SB, Roubin GS, Carlin S, Hearn JA \& Douglas JS. Coronary aneurysms after stent placement - a suggestion of altered vessel wall healing in the presence of anti-inflammatory agents. Journal of the American College of Cardiology 199118 $1524-1528$.

152 Ward MR, Kanellakis P, Ramsey D, Funder J \& Bobik A. Eplerenone suppresses constrictive remodeling and collagen accumulation after angioplasty in porcine coronary arteries. Circulation 2001104 467-472.

153 Adler GK \& Williams GH. Aldosterone: villain or protector? Hypertension $2007 \mathbf{5 0} 31-32$.

154 Patti G, Chello M, Pasceri V, Colonna D, Carminati P, Covino E \& Di GS. Dexamethasone-eluting stents and plasma concentrations of adhesion molecules in patients with unstable coronary syndromes: results of the historically controlled SESAME study. Clinical Therapeutics 200527 1411-1419.

155 Patti G, Pasceri V, Carminati P, D’Ambrosio A, Carcagni A \& Di SG. Effect of dexamethasone-eluting stents on systemic inflammatory response in patients with unstable angina pectoris or recent myocardial infarction undergoing percutaneous coronary intervention. American Journal of Cardiology 200595 502-505.

156 Liu X, Huang Y, Hanet C, Vandormael M, Legrand V, Dens J, Vandenbossche JL, Missault L, Vrints C \& De S. I. Study of antirestenosis with the BiodivYsio dexamethasone-eluting stent (STRIDE): a first-in-human multicenter pilot trial. Catheterization and Cardiovascular Interventions 200360 172-178.

157 Fishel RS, Eisenberg S, Shai SY, Redden RA, Bernstein KE \& Berk BC. Glucocorticoids induce angiotensin-converting enzyme expression in vascular smooth-muscle. Hypertension 199525 343-349.

158 Mendelsohn FAO, Lloyd CJ, Kachel C \& Funder JW. Induction by glucocorticoids of angiotensin converting enzyme production from bovine endothelial cells in culture and rat lung in vivo. Journal of Clinical Investigation 198270 684-692.

159 Morin C, Asselin C, Boudreau F \& Provencher PH. Transcriptional regulation of pre-pro-endothelin-1 gene by glucocorticoids in vascular smooth muscle cells. Biochemical and Biophysical Research Communications $1998 \mathbf{2 4 4}$ 583-587.

160 Mangos G, Walker BR, Kelly JJ, Lawson J. Webb DJ \& Whitworth JA. Cortisol inhibits cholinergic dilatation in the human forearm: towards an explanation for glucocorticoidinduced hypertension. American Journal of Hypertension 200013 $1155-1160$.

161 Huizenga NA, Koper JW, De Lange P, Pols HA, Stolk RP, Burger H, Grobbee DE, Brinkmann AO, de Jong FH \& Lamberts SW. A polymorphism in the glucocorticoid receptor gene may be associated with and increased sensitivity to glucocorticoids in vivo. Journal of Clinical Endocrinology and Metabolism 1998 83 144-151.
162 Van Rossum EFC, Koper JW, Huizenga NATM, Uitterlinden AG, Janssen JAMJ, Brinkmann AO, Grobbee DE, de Jong FH, Van Duyn CM, Pols HAP \& Lamberts SWJ. A polymorphism in the glucocorticoid receptor gene, which decreases sensitivity to glucocorticoids in vivo, is associated with low insulin and cholesterol levels. Diabetes 200251 3128-3134.

163 van Rossum EF, Koper JW, Van Den Beld AW, Uitterlinden AG, Arp P, Ester W, Janssen JA, Brinkmann AO, de Jong FH, Grobbee DE, Pols HA \& Lamberts SW. Identification of the BclI polymorphism in the glucocorticoid receptor gene: association with sensitivity to glucocorticoids in vivo and body mass index. Clinical Endocrinology 200359 585-592.

164 Rosmond R, Chagnon YC, Holm G, Chagnon M, Perusse L, Lindell K, Carlsson B, Bouchard C \& Bjorntorp P. A glucocorticoid receptor gene marker is associated with abdominal obesity, leptin, and dysregulation of the hypothalamic-pituitary-adrenal axis. Obesity Research 20008 211-218.

165 Russcher H, van Rossum EF, de Jong FH, Brinkmann AO, Lamberts SW \& Koper JW. Increased expression of the glucocorticoid receptor-A translational isoform as a result of the ER22/23EK polymorphism. Molecular Endocrinology 2005 19 1687-1696.

166 Schaaf MJ \& Cidlowski JA. AUUUA motifs in the $3^{\prime}$ UTR of human glucocorticoid receptor alpha and beta mRNA destabilize mRNA and decrease receptor protein expression. Steroids $2002 \mathbf{6 7} 627-636$.

167 van Rossum EF, Voorhoeve PG, te Velde SJ, Koper JW, Delemarrevan de Waal HA, Kemper HC \& Lamberts SW. The ER22/23EK polymorphism in the glucocorticoid receptor gene is associated with a beneficial body composition and muscle strength in young adults. Journal of Clinical Endocrinology and Metabolism 200489 4004-4009.

168 van Rossum EF, Feelders RA, Van Den Beld AW, Uitterlinden AG, Janssen JA, Ester W, Brinkmann AO, Grobbee DE, de Jong FH, Pols HA, Koper JW \& Lamberts SW. Association of the ER22/23EK polymorphism in the glucocorticoid receptor gene with survival and C-reactive protein levels in elderly men. American Journal of Medicine 2004117 158-162.

169 van Rossum EF, de Jong FJ, Koper JW, Uitterlinden AG, Prins ND, van Dijk EJ, Koudstaal PJ, Hofman A, de Jong FH, Lamberts SW \& Breteler MM. Glucocorticoid receptor variant and risk of dementia and white matter lesions. Neurobiology of Aging, 2007 In Press.

170 Lin RCY, Wang WYS \& Morris BJ. High penetrance, overweight, and glucocorticoid receptor variant: case-control study. British Medical Journal 1999319 1337-1338.

171 Di Blasio AM, Van Rossum EFC, Maestrini S, Berselli ME, Tagliaferri M, Podesta F, Koper JW, Liuzzi A \& Lamberts SWJ. The relation between two polymorphisms in the glucocorticoid receptor gene and body mass index, blood pressure and cholesterol in obese patients. Clinical Endocrinology $2003 \mathbf{5 9}$ 68-74.

172 Dobson MG, Redfern CPF, Unwin N \& Weaver JU. The N363S polymorphism of the glucocorticoid receptor: potential contribution to central obesity in men and lack of association with other risk factors for coronary heart disease and diabetes mellitus. Journal of Clinical Endocrinology and Metabolism 2001 $862270-2274$

173 Lin RC, Wang XL, Dalziel B, Caterson ID \& Morris BJ. Association of obesity, but not diabetes or hypertension, with glucocorticoid receptor N363S variant. Obesity Research 200311 802-808.

174 Rosmond R, Chagnon YC, Chagnon M, Perusse L, Bouchard C \& Bjorntorp P. A polymorphism of the $5^{\prime}$-flanking region of the glucocorticoid receptor gene locus is associated with basal cortisol secretion in men. Metabolism: Clinical and Experimental 200049 1197-1199.

175 Echwald SM. Sorensen TIA. Andersen T \& Pedersen O. The Asn363ser variant of the glucocorticoid receptor gene is not associated with obesity or weight gain in Danish men. International Journal of Obesity 200125 1563-1565. 
176 Tremblay A, Bouchard L, Bouchard C, Despres J-P, Drapeau V \& Perusse L. Long-term adiposity changes are related to a glucocorticoid receptor polymorphism in young females. Journal of Clinical Endocrinology and Metabolism $2003 \mathbf{8 8}$ 3141-3145.

177 Ukkola O, Perusse L, Chagnon YC, Despres J-P \& Bouchard C. Interactions among the glucocorticoid receptor, lipoprotein lipase and adrenergic receptor genes and abdominal fat in the Quebec Family Study. International Journal of Obesity 200125 1332-1339.

178 Ukkola O, Rosmond R, Tremblay A \& Bouchard C. Glucocorticoid receptor $\mathrm{Bcl} I$ variant is associated with an increased atherogenic profile in response to long-term overfeeding. Atherosclerosis 2001 157 221-224.

179 Clement K, Philippi A, Jury C, Pividal R, Hager J, Demenais F, Basdevant A, Guy-Grand B \& Froguel P. Candidate gene approach of familial morbid obesity: linkage analysis of the glucocorticoid receptor gene. International Journal of Obesity 199620 507-512.

180 Buemann B, Vohl MC, Chagnon M, Chagnon YC, Gagnon J, Perusse L, Dionne F, Despres JP, Tremblay A, Nadeau A \& Bouchard C. Abdominal visceral fat is associated with a Bcll restriction fragment length polymorphism at the glucocorticoid receptor gene locus. Obesity Research 19975 186-192.

181 Weaver JU, Hitman GA \& Kopelman PG. An association between a BcII restriction fragment length polymorphism of the glucocorticoid receptor locus and hyperinsulinaemia in obese women. Journal of Molecular Endocrinology 19929 295-300.

182 Watt GCM, Harrap SB, Foy CJW, Holton DW, Edwards HV, Davidson HR, Connor JM, Lever AF \& Fraser R. Abnormalities of glucocorticoid metabolism and the renin-angiotensin system: a four corners approach to the identification of genetic determinants of blood pressure. Journal of Hypertension 1992 $10473-482$.
183 DeRijk RH, Schaaf MJ, Turner G, Datson NA, Vreugdenhil E, Cidlowski J, de Kloet ER, Emery P, Sternberg EM \& teraWadleigh SD. A human glucocorticoid receptor gene variant that increases the stability of the glucocorticoid receptor betaisoform mRNA is associated with rheumatoid arthritis. Journal of Rheumatology 200128 2383-2388.

184 van den Akker EL, Nouwen JL, Melles DC, van Rossum EF, Koper JW, Uitterlinden AG, Hofman A, Verbrugh HA, Pols HA, Lamberts SW \& van BA. Staphylococcus aureus nasal carriage is associated with glucocorticoid receptor gene polymorphisms. Journal of Infectious Diseases 2006194 814-818.

185 Sudhir K, Jennings GL, Esler MD, Korner PI, Blombery PA, Lambert GW, Scoggins B \& Whitworth JA. Hydrocortisoneinduced hypertension in humans: pressor responsiveness and sympathetic function. Hypertension 198913 416-421.

186 Joffe HV \& Adler GK. Effect of aldosterone and mineralocorticoid receptor blockade on vascular inflammation. Heart Failure Reviews $20051031-37$.

187 Brilla CG \& Weber KT. Mineralocorticoid excess, dietary sodium, and myocardial fibrosis. Journal of Laboratory and Clinical Medicine 1992120 893-901.

188 Galon J, Franchimont D, Hiroi N, Frey G, Boettner A, EhrhartBornstein M, O'Shea JJ, Chrousos GP \& Bornstein SR. Gene profiling reveals unknown enhancing and suppressive actions of glucocorticoids on immune cells. FASEB Journal 200216 61-71.

189 Yeager MP, Guyre PM \& Munck AU. Glucocorticoid regulation of the inflammatory response to injury. Acta Anaesthesiologica Scandinavica $2004 \mathbf{4 8} 799-813$.

Received 10 July 2007

Accepted 20 August 2007 